\title{
Psychological Contract, Organizational Commitment and Work Satisfaction: Survey of Researchers in Chinese State-Owned Engineering Research Institutions
}

\author{
Jianwu Zhou, Michel Plaisent, Lili Zheng, Prosper Bernard \\ La Rochelle Business School, Finland \\ Email: zhengl@esc-larochelle.fr
}

Received July 2014

\section{Abstract}

This research analyzed the effect of knowledge workers' psychological contract on organizational commitment and work satisfaction. Data was collected thru a questionnaire survey given to 517 randomly selected Chinese knowledge workers in two state-owned engineering research institutions. The questionnaire contained items about the demographic profile of the respondents, psychological contract, organizational commitment and work satisfaction. The last three items were answered using a Likert rating scale ranging from 1 to 5 (strongly disagree to strongly agree). Descriptive statistics of the information on demographics was done together with reliability analysis, Pearson correlation and multiple regression of the data on the last three items on the questionnaire. The two dimensions of psychological contract were found to have a significant positive correlation with organizational commitment and work satisfaction. The three dimensions of organizational commitment were found to have a significant positive correlation with work satisfaction. From the regression model it was found that the fulfillment of knowledge workers' psychological contract contributed to the development of increased organizational commitment which in turn contributed to increased knowledge workers' job satisfaction level. This research investigated further the application of psychological contract in Chinese context and bridges the literature gap on analyzing the effects of Chinese psychological contract on work satisfaction through organizational commitment.

\section{Keywords}

Psychological Contract, Organizational Commitment, Job Satisfaction, Chinese Knowledge Workers

\section{Introduction}

Knowledge workers are employees who generate information and apply this information to produce original and creative works. Usually, the position of knowledge workers requires a high level of education, training and pro- 
fessional experience as Research and Development (R \& D) staffs and technical design staffs in research and designing institutes [1]. The knowledge worker is the primary component of the firm's human resources. Knowledge has become one of the most vital resources of companies. The generation of knowledge, its application and value-adding ultimately depends on knowledge workers. However, as the job market for knowledge workers becomes competitive, loyalty to the company is reduced since the major concern of knowledge workers becomes personal without due consideration to organizational stability [2]. Hence, how to increase the researchers' work satisfaction has become the key point of strengthening human resource management in companies.

With the fast changes in market demands, organizations have to adjust to meet and adapt to these changes, which increases employees' work-related stress. On the other hand, the present rapidly-changing life styles have consequently changed individual values. More and more individuals prefer the transition contractual relationship and freedom to several other options. This has triggered the decrease of employee commitment to organizations and job satisfaction which disturbs leaders and managers of organizations [3]. Thus, it becomes necessary to build the appropriate organization-member relationship. Consequently, the psychological contract has become a major concern for scholars. Integrating psychological contract and knowledge worker management is a new direction in knowledge worker management. Presently, the Chinese society is in a transition period. The social economic change and the consequent organizational change have deeply changed the employment relationship between organizations and employees. This largely affects the psychological contract between organizations and employees. The decreasing trust and commitment between organizations and employees, the reduction of job satisfaction level and high turnover rate of core knowledge workers have seriously affected the performance of Chinese companies. Due to the significant cultural and organizational differences between China and the developed countries in the West, the psychological contract theory proposed in the western world may be not suitable in China.

Many current studies of psychological contract in China have considered research employees in their entirety, but lack concrete discussions of employees with different characteristics. A few empirical studies have been concerned with the relationship between psychological contract, organizational commitment and job satisfaction of Chinese knowledge workers. By taking Chinese knowledge workers as samples, this study intends to analyze the relationship among psychological contract, organizational commitment and work satisfaction.

\section{Theoretical Framework and Research Hypothesis}

\subsection{Psychological Contract}

The generalized meaning of psychological contract emphasizes the organization and the individual worker's cognition of their mutually fulfilling responsibilities and obligations. This cognition may come from the formal employment contract or hide in multiple expectations. But in a narrow perspective, psychological contract reflects the collection of employee beliefs about the responsibilities and obligations of both sides based on perception, commitment and trust in the employment relationship [4]. The study of Cassar and Briner [5] discussed that this belief is employees' understanding and perception of the exchange relationship between what employee gives to the organization (competence, effort and loyalty) and what the organization gives in return (reward, promotion and satisfactory work environment). This perception is built based on the subjective understanding of organizational commitment, but the organization may not fulfill its part.

Rousseau [4] classifies psychological contract into two aspects: transactional contract and relational contract. The former is based on the material benefits' satisfaction for both sides. Employees do not become the organizational members really but they are only concerned about the short term material reward and personal benefits. In contrast, relational contract is based on the satisfaction of social affection of both sides, such as organizational support and organizational loyalty. Relational contract reflects employees' affective involvement and belief in organizations because organizations not only provide necessary material reward in return to employees, but also provide guarantees for employees’ work safety, skill training and career development. Many empirical studies have supported these two dimensions of psychological contract.

\subsection{Organizational Commitment}

Most scholars support the view of Meyer and Allen [6] who emphasized that organizational commitment reflects the psychological status between employees and organizations. Organizational commitment implies employee 
determination of whether to stay or not stay in the organization and it contains three dimensions: affective commitment (reflecting employees' affective dependence, identification and involvement in organizations and reflecting employees' willingness to stay in organization as their affection to organization), normative commitment (reflecting employee commitment to stay in organizations as their sense of social responsibility and obligation) and continuance commitment (reflecting employee commitment to stay in organization based on utilitarian consideration). The definition of Meyer and Allen [6] clearly emphasizes that organizational commitment is the employee's psychological perception of the relationship between individuals and organizations and it reflects employee psychological status of being loyal to the organization. Hence, organizational commitment is employees' sense of identification, loyalty, involvement and willingness in organizations based on their affection to organizations, individual benefits and sense of responsibility [7]. In this research, knowledge workers' organizational commitment has three dimensions: affective commitment, continuance commitment and normative commitment.

\subsection{Work Satisfaction}

Usually scholars classify work satisfaction into two aspects: overall satisfaction and specific satisfaction. Overall satisfaction reflects employees' overall love for work or overall attitude towards work, while specific satisfaction reflects employee's feelings in concrete aspects of work [7]. This study defines work satisfaction from an overall perspective as the major goal of this research is to check the effects of psychological contract and organizational commitment on overall work satisfaction of knowledge workers. Hence, work satisfaction is knowledge workers' emotional response and attitude towards the work. This definition is advanced to understand knowledge workers' affective response and attitude from an overall perspective.

\subsection{Effects of Psychological Contract on Organizational Commitment and Work Satisfaction of Knowledge Workers}

Organizational commitment reflects the employee's emotion of voluntary participation in organizational activities with the increasing unilateral investment in organizations. Psychological contract reflects the belief system of employees to mutual responsibility and obligation between individuals and organizations. But the difference between them is that: the content of organizational commitment is unidirectional which only reflects employee emotion to organization, but psychological contract involves the bidirectional relationship which reflects employees' belief to taking responsibilities and the organization taking responsibilities also. In this process, employees will compare and modify the extent of both sides fulfilling the contract, in order to reach the balanced state ultimately [5].

Rousseau [4] has emphasized that organizational commitment is actually the result of psychological contract. Individual cognition, comparison and belief of responsibilities of both sides then make individuals have different commitment ways and levels in organizations. Psychological contract reflects employee's subjective belief of the responsibility and obligation between individuals and organizations. Whether the right expectation in psychological contract is realized or not, has an important effect on knowledge workers. With the right expectation, the material guarantee is to provide high level of reward, pay for performance, promotion and development. These material guarantees have a large effect on knowledge workers' decision about whether they will stay in the organization and affect their emotional dependence and involvement in organizations. The interpersonal support and internal development expectation has correlation with long term work guarantee, career development, good interpersonal environment and social emotional exchanges. These aspects will affect knowledge workers' love for the organization, which then affects whether they stay or not in the organization. The study of Luo and Yu [8] analyzed the effect of psychological contract on organizational commitment of knowledge workers. They found that transactional contract has a significant negative effect on organizational commitment but relational contract has a positive influence.

In aspect of the link between organizational commitment and work satisfaction, scholars do not have a consistent view. Some scholars [9] viewed work satisfaction as the antecedent of organizational commitment and argued that there is a positive correlation between them. These scholars argued that knowledge workers who have a higher level of work satisfaction will transfer the active work attitude into increased organizational commitment. Compared with organizational commitment, work satisfaction changes more readily and is largely unstable. Hence, work satisfaction can be viewed as the antecedent of organizational commitment. The study of 
Yamaguchi [7] also argued that knowledge workers' high level of organizational commitment is mainly contributed by a high level of work satisfaction. However, some scholars have the opposite view that organizational commitment is the antecedent of work satisfaction. This view supposes that individuals actively adjust their work satisfaction level in order to adapt to the current situation of organizational commitment. This research supports the latter view by discussing the effect of psychological contract and organizational commitment on work satisfaction of knowledge workers.

Research hypothesis:

H1: Chinese knowledge workers' psychological contract has a significant positive effect on organizational commitment.

H2: Chinese knowledge workers' organizational commitment has a significant positive effect on work satisfaction.

H3: Organizational commitment has a mediating effect on the relationship between Chinese knowledge workers' psychological contract and work satisfaction.

\section{Methodology}

\subsection{Questionnaire Design and Data Process Methods}

This research employed a questionnaire survey to gather primary data to test the research hypotheses, in order to seek the effects of knowledge worker psychological contract on organizational commitment and job satisfaction (Figure 1). The questionnaire had four parts. The first part referred to the samples' background information. The second to fourth part pertained to the scale of psychological contract, scale of organizational commitment and scale of work satisfaction respectively. The instrument used a five-point Likert scale ranging from 1 to 5 , representing the respondents' level of agreement with each of the items, 1 represents strongly disagree and 5 represents strongly agree. This research used SPSS 15.0 software for descriptive statistical analysis, reliability analysis, Pearson correlation and multiple regression analysis.

\subsection{Samples and questionnaire distribution}

This research selected randomly knowledge workers in two Chinese state-owned engineering research institutions in the same industry. In this study, the knowledge workers consisted not only of professional staff that perform R\&D tasks, but also included staff who support and assist the R\&D tasks such as lab administrators. The respondents of the questionnaire survey in this research were 517 knowledge workers in different departments and positions in the two Chinese engineering research institutions.

\section{Results, Analysis and Discussions}

\subsection{Demographic Profile of the Samples}

The descriptive analysis of samples is given in Table $\mathbf{1}$.

\subsection{Data Reliability Test}

In a rating scale, reliability reflects the consistency or stability of the resulting measurements. This research applied Cronbach Alpha coefficient as an indicator of reliability. The data can be seen in Table 2.

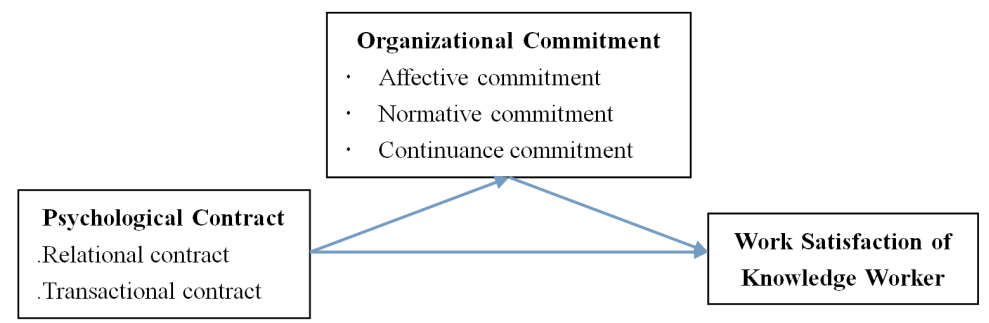

Figure 1. Effect of knowledge worker's psychological contract on organizational commitment and work satisfaction 
Table 1. Descriptive statistical analysis.

\begin{tabular}{|c|c|c|c|c|c|}
\hline & Characteristic & Frequency & $\begin{array}{l}\text { \% of frequency in } \\
\text { valid samples }\end{array}$ & $\begin{array}{c}\text { \% of frequency in } \\
\text { total samples }\end{array}$ & $\%$ of valid samples \\
\hline \multirow{2}{*}{ Gender } & Male & 248 & 48 & 51.1 & \multirow{2}{*}{93.8} \\
\hline & Female & 235 & 45.5 & 48.5 & \\
\hline \multirow{8}{*}{ Age } & $<25$ years & 12 & 2.3 & 2.5 & \multirow{8}{*}{94.2} \\
\hline & $26-30$ & 52 & 10.1 & 10.7 & \\
\hline & $31-35$ & 63 & 12.2 & 12.9 & \\
\hline & $36-40$ & 122 & 23.6 & 25.1 & \\
\hline & $41-45$ & 118 & 22.8 & 24.2 & \\
\hline & $46-50$ & 83 & 16.1 & 17 & \\
\hline & $51-55$ & 26 & 5 & 5.3 & \\
\hline & $56-60$ & 11 & 2.1 & 2.3 & \\
\hline \multirow{2}{*}{ Civil status } & Married & 434 & 83.9 & 90.6 & \multirow{2}{*}{92.6} \\
\hline & Unmarried & 44 & 8.5 & 9.2 & \\
\hline \multirow{5}{*}{ Education level } & Postgraduate or higher & 93 & 18 & 19.1 & \multirow{5}{*}{94.2} \\
\hline & University & 200 & 38.7 & 41.1 & \\
\hline & Junior college & 121 & 23.4 & 24.8 & \\
\hline & Polytechnic school & 47 & 9.1 & 9.7 & \\
\hline & High school or less & 26 & 5 & 5.3 & \\
\hline \multirow{7}{*}{$\begin{array}{l}\text { Number of years } \\
\text { of work in the } \\
\text { company }\end{array}$} & $<5$ years & 65 & 12.6 & 13.7 & \multirow{7}{*}{91.9} \\
\hline & $6-10$ & 54 & 10.4 & 11.4 & \\
\hline & $11-15$ & 91 & 17.6 & 19.2 & \\
\hline & $16-20$ & 104 & 20.1 & 21.9 & \\
\hline & $21-30$ & 123 & 23.8 & 25.9 & \\
\hline & $31-40$ & 34 & 6.6 & 7.2 & \\
\hline & $>41$ years & 4 & 0.8 & 0.8 & \\
\hline \multirow{4}{*}{$\begin{array}{l}\text { Classification } \\
\text { of Job title }\end{array}$} & Senior & 93 & 18 & 19.3 & \multirow{4}{*}{93} \\
\hline & Medium-grade & 224 & 43.3 & 46.6 & \\
\hline & Junior & 101 & 19.5 & 21 & \\
\hline & Others & 28 & 5.4 & 5.8 & \\
\hline
\end{tabular}

According to Table 2, the Cronbach Alpha coefficients of the three scales are 0.863, 0.911and 0.805, which are all higher than 0.8 . Hence, the items in the three scales have a high level of reliability, and they can be used for the subsequent statistical processing.

\subsection{Correlation Analysis and Regression Analysis}

Table 3 presents the Pearson correlation analysis of psychological contract, organizational commitment and work satisfaction. Based on this table, it can be seen that two dimensions of psychological contract have a very significant positive correlation with the three dimensions of organizational commitment; two dimensions of psychological contract have a very significant positive correlation with work satisfaction; three dimensions of 
Table 2. Results of the reliability test.

\begin{tabular}{ccc}
\hline Scale & Number of items & Cronbach's alpha coefficient \\
\hline Scale of psychological contract & 10 & 0.863 \\
Scale of organizational commitment & 15 & 0.911 \\
Scale of work satisfaction & 4 & 0.805 \\
\hline
\end{tabular}

Table 3. Pearson correlation analysis of psychological contract, organizational commitment and work satisfaction

\begin{tabular}{|c|c|c|c|c|c|c|}
\hline & $\begin{array}{c}\text { Transactional } \\
\text { contract }\end{array}$ & $\begin{array}{c}\text { Relational } \\
\text { contract }\end{array}$ & $\begin{array}{c}\text { Affective } \\
\text { commitment }\end{array}$ & $\begin{array}{c}\text { Normative } \\
\text { commitment }\end{array}$ & $\begin{array}{l}\text { Continuance } \\
\text { commitment }\end{array}$ & $\begin{array}{c}\text { Work } \\
\text { satisfaction }\end{array}$ \\
\hline 1.Transactional contract & 1 & & & & & \\
\hline 2.Relational contract & $00.251^{* *}$ & 1 & & & & \\
\hline 3.Affective commitment & $0.324^{* *}$ & $0.333^{* *}$ & 1 & & & \\
\hline 4.Normative commitment & $0.301^{* *}$ & $0.226^{* *}$ & $0.124^{* *}$ & 1 & & \\
\hline 5.Continuance commitment & $0.281^{* *}$ & $0.294^{* *}$ & $0.167^{* *}$ & $0.125^{* *}$ & 1 & \\
\hline 6.Work satisfaction & $0.415^{* *}$ & $0.226^{* *}$ & $0.615^{* *}$ & $0.295^{* *}$ & $0.328^{* *}$ & 1 \\
\hline
\end{tabular}

Note: ${ }^{*} \mathrm{p}<0.05 ;{ }^{* *} \mathrm{p}<0.01$ (two - tailed)

organizational commitment have a very significant positive correlation with work satisfaction.

\subsubsection{Dependent Variable: Organizational Commitment}

In Table 4 the two dimensions of psychological contract are considered as independent variables and organizational commitment as dependent variable for regression analysis. The result shows that both transactional contract and relational contract have a significant positive effect on organizational commitment. The regression coefficients are 0.267 and 0.229 , which are significant at 0.01 level. Hence, the satisfaction of knowledge workers' psychological contract will significantly increase their commitment to the organization. Hypothesis H1 is supported.

\subsubsection{Dependent Variable: Work Satisfaction}

In Table 5 the three dimensions of organizational commitment are the independent variables and work satisfaction is the dependent variable in regression. The result shows that affective commitment, normative commitment and continuance commitment all have a significant positive effect on work satisfaction. Regression coefficients are $0.406,0.103$ and 0.249 , which are significant at 0.01 level. Hence, the increasing of knowledge workers' organizational commitment will significantly increase their work satisfaction. Thus, H2 hypothesis is supported.

\subsubsection{Dependent Variable: Work Satisfaction}

In order to test the $\mathrm{H} 3$ hypothesis, the regression model considered psychological contract as independent variable, organizational commitment as mediating variable and work satisfaction as dependent variable. The result is presented in Table 6. According to Table 6, after adding the mediating variable of organizational commitment (model 3), the regression coefficient of organizational commitment for work satisfaction is still significant at level of 0.001 , and the regression coefficient of psychological contract for work satisfaction is also significant at level of 0.001 and this regression coefficient reduces from 0.455 (model 2) to 0.335 (model 3). This implies that organizational commitment has partial mediating effect on the link between psychological contract and work satisfaction. The satisfaction of knowledge workers' psychological contract will cause the increased organizational commitment, which eventually contributes to increase in work satisfaction. Hence, the third hypothesis of H3 is supported.

\subsection{Empirical Results and Discussions}

First of all, the hypothesis of $\mathrm{H} 1$ is supported. Two dimensions of psychological contract (including both trans- 
Table 4. Regression analysis of psychological contract and organizational commitment

\begin{tabular}{|c|c|c|c|c|}
\hline & \multirow{2}{*}{ Independent variables } & Standardized Regression Coefficients & \multirow{2}{*}{$\mathrm{t}$} & \multirow{2}{*}{ Sig. } \\
\hline & & Beta & & \\
\hline \multirow{3}{*}{1} & (Constant) & & 8.126 & 0.000 \\
\hline & Transactional contract & $0.267^{* *}$ & 2.991 & 0.005 \\
\hline & Relational contract & $0.229^{* *}$ & 2.628 & 0.004 \\
\hline
\end{tabular}

Note: ${ }^{*} \mathrm{p}<0.05 ;{ }^{* *} \mathrm{p}<0.01$ (two - tailed)

Table 5. Regression analysis of organizational commitment and work satisfaction

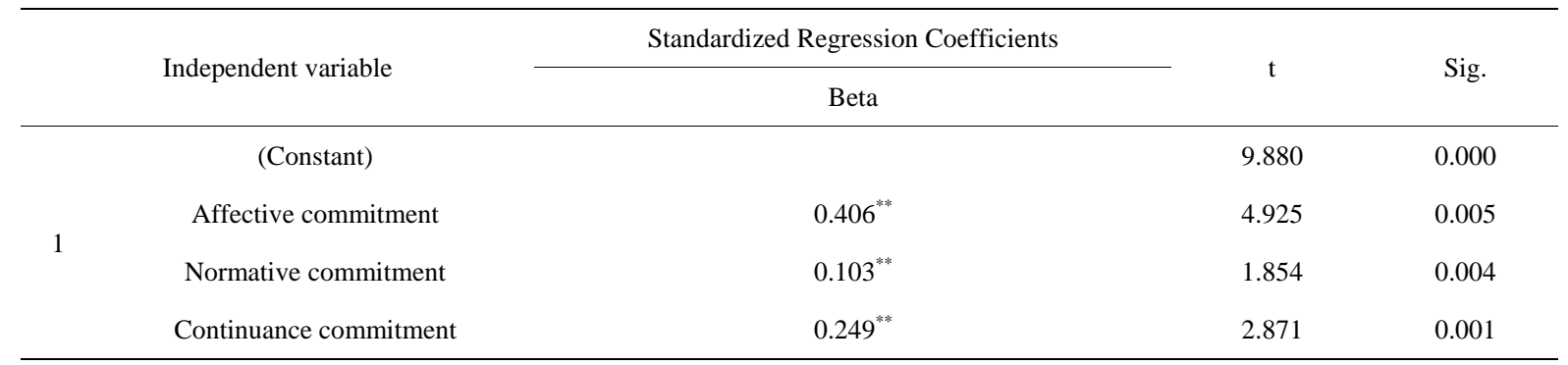

Note: ${ }^{*} \mathrm{p}<0.05 ;{ }^{* *} \mathrm{p}<0.01$ (two - tailed)

Table 6. Mediating effect of organizational commitment.

\begin{tabular}{ccccc}
\hline \multirow{2}{*}{ Regression model } & Dependent variable & Independent variables & Standardized Regression Coefficients & Sig. \\
\hline 1 & Work satisfaction & Psychological contract & $0.455^{* * *}$ & 0.000 \\
2 & Organizational commitment & Psychological contract & $0.598^{* * *}$ & 0.000 \\
3 & Work satisfaction & Psychological contract & $0.335^{* * *}$ & 0.000 \\
& & Organizational commitment & $0.253^{* * *}$ & 0.000 \\
\hline
\end{tabular}

Note: ${ }^{*} \mathrm{p}<0.05 ;{ }^{* *} \mathrm{p}<0.01 ;{ }^{* * *} \mathrm{p}<0.001$ (two - tailed).

actional contract and relational contract) all play a significant role on the knowledge workers' commitment to organization. Through regression analysis of the relationship between knowledge workers' psychological contract and organizational commitment, this study finds that psychological contract has a significant positive impact on organizational commitment. In other words, the improvement in the fulfillment of the psychological contract will contribute to a higher level of knowledge workers' organizational commitment [8]. On one hand, the better fulfillment of psychological contract will make knowledge workers form a more intense affective identification with the organization. Then they will feel more proud of being organizational members. When knowledge workers perceive that the firm has fulfilled the psychological contract better, respondents will have a large positive effect on their commitment to the organization, which is felt when the organization provides for a more harmonious interpersonal atmosphere and shows a more intense care about its employees. On the other hand, according to Cassar and Briner [5], a psychological contract breach will weaken knowledge workers' identification with the organization. When knowledge workers think the psychological contract is not fulfilled, they will lose their trust on the organization and they will no longer identify with the firm. How Chinese state-owned engineering research institutions fulfill their commitments and obligations to knowledge workers largely determine their perceived satisfaction with the psychological contract. Consequently, this affects knowledge workers' commitment to the organization. The satisfaction of transactional contract involves providing sufficient material incentive and added stock option incentive to knowledge workers. This is done to reduce the fast turnover rate of knowledge workers, which then plays a significant effect on continuance and normative dimensions of organizational commitment. The satisfaction of relational contract involves providing long term favorable work guarantee and advanced career development to knowledge workers, in order to cultivate their 
positive feelings towards the organization. Consequently this plays a significant effect on continuance commitment and affective commitment of knowledge workers.

Secondly, H2 hypothesis is also supported. The three dimensions of organizational commitment namely affective commitment, normative commitment and continuance commitment all have a significant positive effect on work satisfaction of knowledge workers. Based on statistical analysis, this study finds a significant positive impact of organizational commitment on work satisfaction. In other words, knowledge workers with higher level of organizational commitment then have higher level of satisfaction with the working operational procedures This result is consistent with studies of Eslami and Gharakhani [3] and Zopiatis et al. [10]. Knowledge workers will be more proud of being organizational members if they have higher level of affective identification and involvement with the organization. This positive emotion then will be brought to work, which is advantageous in increasing work satisfaction. Affective commitment reflects employee's affective dependence, involvement and identification with the organization [6]. Knowledge workers with a higher level of affective commitment show more intense identification with the firm's idea, concept and value. Also, the individual value becomes more consistent with the organizational value, which then causes a higher loyalty of knowledge workers to companies [11]. Knowledge workers with a high level of organizational commitment show a higher trend to accept the firm's actual work condition and environment. They try to integrate into the firm environment actively; as a result they show high level of satisfaction in the work. Normative commitment reflects the employee's sense of obligation and responsibility to stay in the organization [6]. Knowledge workers with high level of normative commitment have strong self-control and they view the work in the organization as their responsibility and obligation. Also they view themselves are members of the organization. Even in the presence of competitive a environment with external incentives (such as higher level of compensations in other companies), knowledge workers with high level of normative commitment keep being loyal to their current organizations and will not leave the company. These employees definitely show a high level of work satisfaction.

Thirdly, H3 hypothesis is supported by the empirical analysis. Knowledge workers with different satisfaction levels of psychological contract will perceive different levels of work satisfaction. But simultaneously, organizational commitment influences the effect of knowledge workers' psychological contract on work satisfaction. The statistical analysis of this research shows that organizational commitment plays partially a mediating effect on the link between psychological contract and work satisfaction. According to social exchange theory and equity theory, it is the mutually beneficial relationship between organizations and employees, which requires both sides to have pay out and return in exchange. This mutually beneficial relationship is not only clearly shown in the formal employment contract, but also exists in employee psychology with the potentially mutual expectation and understanding (which refers to the psychological contract of employee). For instance, employees expect organizations can provide learning and training opportunities, can give the good humane care and social support and can provide promotion development based on employee's work performance. On the other side, organizations expect employees to be loyal to the organization, work actively and make contributions consistently for the firm's development. When knowledge workers think the psychological contract is satisfied, they will form a strong sense of identification and loyalty to the organization and they feel proud of being organizations members. As such, they feel they have obligations and responsibilities to work in the organization. This then brings a high level of organizational commitment, which finally causes a high level of work satisfaction of employees. The finding of this research provides exploratory evidence for analyzing the mediating variable between psychological contract satisfaction and work output. For instance, the study of Alniacik et al. [12] has found that organizational commitment has a mediating role on the effect of expectation satisfaction and work satisfaction. Also, this finding shows the mechanism of psychological contract satisfaction affecting organizational commitment and work satisfaction. When knowledge workers' psychological contract is satisfied (the required obligation of organizations is effectively fulfilled), they will perceive the physical and psychological incentives. Based on the principle of mutual benefit, knowledge workers will increase their commitment to organizations, which then increases their work satisfaction. This finding also implies that companies should be concerned with the psychological contract of knowledge works in human resource management.

\section{Conclusions and Recommendations}

This research reviewed literatures about psychological contract, organizational commitment and work satisfaction initially. Then it proposed hypotheses showing the relationship among psychological contract, organiza- 
tional commitment and work satisfaction. This study employed a survey questionnaire to Chinese knowledge workers. Data was processed by SPSS software. It finds that: firstly, the satisfaction of knowledge workers' psychological contract will increase the organizational commitment; secondly, the increased knowledge workers' commitment to organizations will cause the increased work satisfaction; lastly, the satisfaction of knowledge workers' psychological contract will increase their work satisfaction through increased organizational commitment.

Hence, Chinese companies should be concerned about effective communication with knowledge workers concerning psychological contract. Especially, firm's HR departments and direct supervisors of knowledge workers should provide support to enhance the satisfactory implementation of the psychological contract and communicate the firm's expectations to knowledge workers. They should understand the real expectation of knowledge workers in order to reduce the non-compliance of the psychological contract, which is then advantageous towards increasing the organizational commitment of knowledge workers.

Due to the limitations of research time and funding, the sample size of this research may not be large enough. This study collected 517 copies of questionnaires from Chinese knowledge workers. However, the representativeness of the sample may not be adequate, which will limit the generalization of the research conclusions. Hence, the future researches may consider collecting samples covering a wider range of Chinese knowledge workers in different types of companies, in order to increase the sample representativeness and generalization of conclusion.

\section{References}

[1] Gumusluoglu, L., Karakitapoglu-Aygun, Z. and Hirst, G. (2013) Transformational Leadership and R \& D Workers’ Multiple Commitments: Do Justice and Span of Control Matter? Journal of Business Research, 66, 2269-2278. http://dx.doi.org/10.1016/j.jbusres.2012.02.039

[2] Robertson, M.M., Huang, Y.H., O’Neill, M.J. and Schleifer, L.M. (2008) Flexible Workspace Design and Ergonomics Training: Impacts on the Psychosocial Work Environment, Musculoskeletal Health, and Work Effectiveness among Knowledge Workers. Applied Ergonomics, 39, 482-494. http://dx.doi.org/10.1016/j.apergo.2008.02.022

[3] Eslami, J. and Gharakhani, D. (2012) Organizational Commitment and Job Satisfaction. ARPN Journal of Science and Technology, 2, 85-91.

[4] Rousseau, D.M. (1995) Psychological Contracts in Organizations: Understanding Written and Unwritten Agreements. Sage, Newbury Park, CA.

[5] Cassar, V. and Briner, R.B. (2011) The Relationship between Psychological Contract Breach and Organizational Commitment: Exchange Imbalance as a Moderator of the Mediating Role of Violation. Journal of Vocational Behavior, 78, 283-289. http://dx.doi.org/10.1016/j.jvb.2010.09.007

[6] Meyer, J.P. and Allen, N.J. (1991) A Three-Component Conceptualization of Organizational Commitment. Human Resources Management Review, 1, 61-89. http://dx.doi.org/10.1016/1053-4822(91)90011-Z

[7] Yamaguchi, I. (2013) A Japan-US Cross-Cultural Study of Relationships among Team Autonomy, Organizational Social Capital, Job Satisfaction, and Organizational Commitment. International Journal of Intercultural Relations, 37, 58-71. http://dx.doi.org/10.1016/j.ijintrel.2012.04.016

[8] Luo, J. and Yu, M.F. (2013) A Study of Knowledge Staffs' Loyalty Based on the Psychological Contract. Journal of Xi'an Shiyou University (Social Science Edition), 1, 50-54.

[9] Altinoz, M., Cakiroglu, D. and Cop, S. (2012) The Effect of Job Satisfaction of the Talented Employees on Organizational Commitment: A Field Research. Procedia-Social and Behavioral Sciences, 58, 322-330.

[10] Zopiatis, A., Constanti, P. and Theocharous, A.L. (2014) Job Involvement, Commitment, Satisfaction and turnover: Evidence from Hotel Employees in Cyprus. Tourism Management, 41, 129-140. http://dx.doi.org/10.1016/j.tourman.2013.09.013

[11] Si, S., Wei, F. and Li, Y. (2008) The Effect of Organizational Psychological Contract Violation on Managers’ Exit, Voice, Loyalty and Neglect in the Chinese Context. International Journal of Human Resource Management, 19, 932944.

[12] Alniacik, E., Alniacik, U., Erat, S. and Akcin, K. (2013) Does Person-Organization Fit Moderate the Effects of Affective Commitment and Job Satisfaction on Turnover Intentions? Procedia-Social and Behavioral Sciences, 99, $274-281$. 